\title{
EDITORIAL WELCOME
}

\section{Special Issue on Ethnocracy}

This Special Issue of Cosmopolitan Civil Societies Journal focuses on the domination of social and political relations by Ethnocracy - rule or would-be rule by an ethnic group or ethnos, as distinct from Democracy or rule by the demos of all the people. Ethnocracy encompasses state regimes and associated political movements and parties that discriminate systematically in favour of a particular ethnic group (or groups) and against others. When we proposed the Special Issue in late 2014 ethnocratic practices were as prevalent as they had ever been; and now two years later they appear to be on the increase with an ethno-populist upsurge and the election or threatened election of governments pursuing ethnocratic agendas. From India to the USA, from Russia to Hungary, leading politicians openly discriminate against ethnic 'others' to attract support from 'their own' ethnic groups; across the European Union and in other liberal democracies they increasingly scapegoat 'immigrants' to hide their own inadequacies and further their political objectives. Now, more than ever, it is critical that the dynamics of ethnocracy are more clearly understood. This Issue documents the logics of ethnocracy in a variety of different contexts, posing questions about how it develops and how it can be challenged.

Ethnocracy may be formal with discrimination enshrined in law (as in Apartheid South Africa), or it may be more informal with apparent or formal equalities masking very unequal realities (as happened in Northern Ireland). As discussed later in more detail, the concept was most notably developed by the Israeli geographer Oren Yiftachel to analyse Israel-Palestine and Jewish-Palestinian relations; and this Special Issue develops it further in other national contexts, including Sri Lanka, Latvia and Estonia, Fiji and Australia, and in the urban contexts of Jerusalem and Beirut. The different cases of ethnocracy point to its varied forms and degrees of severity, ranging from everyday petty or not-so-petty discrimination to state- 
sponsored military assault, its practices generally characterized by exclusion and violence actual or incipient.

The Issue originated in a public lecture delivered in November 2014 by James Anderson during a research visit to the University of Technology Sydney. The lecture has been developed into the refereed 'lead article' where he advances a number of arguments which the other contributors were invited to consider, explore or reject, whether in whole or in part. He argues that the idea of Ethnocracy can be extended and applied to different types of political context beyond the national state and urban governance for which it was developed in Israel-Palestine. So in addition to National and Urban ethnocracy, there are Imperial, 'Post-Conflict' and 'Post-National/Religious' ethnocracies, and each of the five types has its own distinct dynamics.

Imperial ethnocracy extends 'back' to earlier roots in traditional empires and their politicization of different ethnicities, defined in religious, linguistic or wider cultural terms (e.g., in the Ottoman, British and French empires in the Balkans and Middle East). Its dynamics sometimes involved three-way relationships between the imperial power, indigenous peoples, and also 'settlers' (as in the British Empire in Ireland, Palestine, South Africa and Australia). Then, looking 'forward', the concept has direct relevance in supposedly post-conflict national contexts, where lethal conflict has (mostly) been stopped but the conflict typically continues along the same ethnic lines (as in Bosnia, Northern Ireland, and Sri Lanka). Fifthly, and more tentatively, the concept might possibly be useful in post-national contexts where national objectives have been at least partly displaced by transnational religion as the major motivator in its own right, radical Islam and fundamentalist Christianity the most obvious examples.

Contributors respond in various ways to these ideas. Oren Yiftachel debates the present condition of ethnocratic theory, and reflects on the possibilities for further extensions as 'offsprings' of ethnocracy, demonstrating the rich insights the concept can bring. Following Yiftachel's commentary, there are refereed articles that reflect in detail on the practice of ethnocracy in widely different situations. Nirmanusan Balasundaram discusses Sri Lanka, highlighting the continuing ethnocratic dynamics of an ostensibly 'post-conflict' society. Konstantin Kastrissianakis focuses on the fractious urban history of Beirut, as a site of ethnocratic conflict along religious lines. Timofey Agarin takes us to a dramatically different 
context, in the Baltic States, yet one also riven with ethnic majoritarianism and geopolitical rivalry. Haim Yacobi focuses on the urban context of Jerusalemlal-Quds, debating the differences and similarities between ethnocracy and urban apartheid. Sanjay Ramesh documents the oscillation between post-colonial ethnocracy and democracy in Fiji. Andrew Jakubowicz highlights the reappearance of ethnicised immigration debates in Australia, and the reciprocal counter-assertion and reassertion of ethnic exclusion which this is generating.

To borrow a phrase from the Irish republican and Marxist, James Connolly, ethnocracies create their own 'carnival of reaction'. Across all the cases discussed, the dynamics of the carnival stem from the exercise or attempted exercise of exclusionary power, typically wielded in authoritarian ways. Understanding the dynamics is essential for defending and extending meaningful democratic relations.

James Goodman ${ }^{1}$ and James Anderson ${ }^{2}$ (Guest Editors)

November 2016

\footnotetext{
${ }^{1}$ James Goodman, Faculty of Arts and Social Sciences, University of Technology Sydney.

${ }^{2}$ James Anderson, Emeritus Professor, The Senator George J Mitchell Institute for Global Peace, Security and Justice, Queen's University Belfast
} 